\title{
SCIDiC
}

International Journal of Dentistry and Oral Science (IJDOS)

ISSN: 2377-8075

\section{Recent Advances In Drugs Used As Endodontic Irrigants - A Literature Review}

Research Article

Dr. P. Niharika ${ }^{1}$, Dr. Subash Sharma ${ }^{2 *}$

${ }^{1}$ Department of Conservative Dentistry and Endodontics, Saveetha Dental College and Hospital, Saveetha Institute of Medical and Technical Sciences, Saveetha University, Chennai, India

${ }^{2}$ Head of the Department, Department of Aesthetic dentistry, Saveetha Dental college and Hospital ,Saveetha Institute of Medical and Technical Sciences, Saveetha University, Chennai, India

\section{Abstract}

Bacteria have long been recognized as the primary etiologic factors in the development of pulp and periapical lesions. The primary objective of endodontic treatment relies on the chemical and mechanical debridement of root canals. This article narrates the specifics and requirements of the irrigation solutions. This review is aimed to bring some light over the advances in root canal disinfection reviewing the newly used irrigants.

Keywords: Disinfection, Root Canal Treatment, Advanced Techniques, Endodontic Irrigants.

\section{Introduction}

Microorganisms and their toxic metabolic products have long been responsible for the development and persistence of apical periodontitis of endodontic origin.[1]

The effectiveness of endodontic files, rotary instrumentation, irrigating solutions, and chelating agents to clean, shape, and disinfect root canals underpins the success, longevity, and reliability of modern endodontic treatments. [2,3]. However, if microorganisms persist at the time of obturation, or if they penetrate into the canal after obturation, there is a high risk of treatment failure.[4] It is generally believed that mechanical enlargement of canals must be accompanied by copious irrigation in order to facilitate maximum removal of microorganisms so that the prepared canal becomes as bacteria-free as possible.[5,6]

This article reviews recent developments in the identification of new agents to sterilize infected root canal. Previously our team has a rich experience in working on various research projects across multiple disciplines [7-21] Now the growing trend in this area motivated us to pursue this project.

\section{Ideal Requirement Of Root Canal Irrigants}

Root canal irrigants must ideally be[22] (i) have a broad antimicrobial spectrum and high efficacy against anaerobic and facultative microorganisms organized in biofilms,

(ii) dissolve necrotic pulp tissue remnants,

(iii) inactivate endotoxin,

(iv) prevent the formation of a smear layer during instrumentation or dissolve the latter once it has formed,

(v) be systemically nontoxic,

(vi) be non caustic to periodontal tissues,

(vii) be little potential to cause an anaphylactic reaction.

\section{Newer Root Canal Irrigants}

Newer root canal irrigants are are as follows:

(1) QMix

(2) Triclosan and Gantrez

(3) Electrochemically activated solutions,

(4) ozonated water

(5) Silver diamine fluoride

(6) HEBP

(7) photon-activated disinfection

(8) Antibiotic intracanal medicaments

(9) herbal irrigants.

\section{QMix}

*Corresponding Author:

Dr. Subash Sharma,

Head of the Department, Department of Aesthetic dentistry, Saveetha Dental college and Hospital ,Saveetha Institute of Medical and Technical Sciences, Saveetha University,

Chennai, India

Tel : +919884533118

E-mail : subash@saveetha.com

Received: Mayr 04, 2021

Accepted: July 09,2021

Published: July 17, 2021

Citation: P. Niharika, Subash Sharma. Recent Advances In Drugs Used As Endodontic Irrigants - A Literature Review. Int J Dentistry Oral Sci. 2021;8(7):3246-3251. doi: http://dx.doi.org/10.19070/2377-8075-2100066

Copyright: Dr. Subash Sharma ${ }^{\circ}$ 2021. This is an open-access article distributed under the terms of the Creative Commons Attribution License, which permits unrestricted use, distribution and reproduction in any medium, provided the original author and source are credited. 
QMix, a product that is composed of a polyamino carboxylic acid chelating agent, a bisbiguanide antimicrobial agent, a surfactant, and deionized water[23].Qmix is a novel irrigating solution which is been used for the removal of smear layer and also for disinfection with added antibacterial agents as it contains EDTA, Chlorhexidine and water. As it is a clear solution which is ready to use with no chairside mixing required. Previous studies have reported that the efficacy is increased with the use of Qmix in root canal disinfection[80] [81] .Furthermore, QMix ${ }^{\text {TM }}$ does not interact with remnant $\mathrm{NaOCl}$ to generate a precipitate if used as directed for the final rinse and its ability to penetrate into patent, smear plug-free dentin to kill bacteria present has been demonstrated using a novel model with potentially significant clinical outcomes and implications [24].

\section{Triclosan And Gantrez}

Triclosan is a broad spectrum antimicrobial agent, active against gram-positive and gram-negative bacteria as well as some fungi and viruses[25, 26]Nudera et al.[27] evaluated the minimum inhibitory concentrations (MIC) and minimum bactericidal concentrations $(\mathrm{MBC})$ of triclosan and triclosan with Gantrez ${ }^{\circledR}$ against $\mathrm{P}$ intermedia, $\mathrm{F}$ nucleatum, A naeslundii, $\mathrm{P}$ gingivalis, and $\mathrm{E}$ faecalis. The MBC of triclosan ranged from $12-94 \mu \mathrm{g} / \mathrm{ml}$. The MBC of triclosan with Gantrez ${ }^{\circledR}$ ranged from $<0.3-10.4 \mu \mathrm{g} / \mathrm{ml}$. The addition of Gantrez ${ }^{\circledR}$ enhanced the bactericidal activity of triclosan. Both triclosan and triclosan with Gantrez ${ }^{\circledR}$ demonstrated bactericidal activity against the five specific endodontic pathogens.

\section{Electrochemically Activated Solution}

The ECA technology was developed by Russian scientists at the All-Russian Institute for Medical Engineering (Moscow, Russia, CIS). Principle of ECA is transferring liquids into a metastable state via an electrochemical unipolar (anode or cathode) action through the use of an element/reactor ("Flow-through Electrolytic Module" or FEM). Anolyte solution has been termed Superoxidized Water or Oxidative Potential Water. Depending on the type ECA device that incorporated the FEM elements the $\mathrm{pH}$ of anolyte varies; it may be acidic (anolyte), neutral (anolyte neutral), or alkaline (anolyte neutral cathodic)[28, 29]. The quality of debridement was better in the coronal and middle parts of canal walls where only scattered debris was noted in contrast to the apical part that contained numerous debris. This observation confirms the previously published results[30].

\section{Laser Activation Irrigants}

The laser technology had evolved recently and showed relatively better results and safety which was proposed for various dental treatments such as reducing the tooth sensitivity, root canal preparation, removing caries, disinfecting the dental tissues and bleaching. Some of the effects of lasers which include vaporization of soft tissue, melting of dentin surfaces, removal of smear layer or intracanal medicament. The mechanism of the laser activation devices with irrigating solutions originates from the absorption of laser energy, formation of vapor bottles, acoustic streaming which finally leads to cavitation[80]. Lasers which have been widely used in the dental field for disinfection of the root canal are $\mathrm{Co} 2, \mathrm{Nd}: \mathrm{YAG}, \mathrm{ER}: Y S G G, \mathrm{Nd}: \mathrm{YAG}$, argon and diode lasers which have been used for root canal disinfection. It has been stated in previous studies that the photothermal property of diode lasers in the root canal can increase the temperature of the irrigant at any concentration[83] .

\section{Ozonated Water}

Ozone is a very powerful bactericide that can kill microorganisms effectively. It is an unstable gas, capable of oxidizing any biological entity. It was reported that ozone at low concentration $0.1 \mathrm{ppm}$, is sufficient to inactivate bacterial cells including their spores[31]. Shockwave generation can also enhance the breakdown of agents such as hydrogen peroxide and ozone dissolved in water and thereby enhance their disinfecting and debriding actions $[32,33]$

Study by Hems et al. however found that $\mathrm{NaOCI}$ was superior to ozonated water in killing E. faecalis in broth culture and in biofilm[34]. Ibrahim and Abdullah studied that 1.31\% NaOCI might allow passage of oxidation of ozonated water, thus increasing their antibacterial effect compared to $1.31 \% \mathrm{NaOCI}$ or ozonated water alone [35].

\section{Silver Diamine Fluoride}

A 3.8\% w/v silver diamine fluoride ( $\mathrm{Ag}[\mathrm{NH} 3] 2 \mathrm{~F}$ ) solution has been developed for intracanal irrigation. This represents a 1:10 dilution of the original $38 \% \operatorname{Ag}(\mathrm{NH} 3$ ) $2 \mathrm{~F}$ solution used for root canal infection.[36] The study on the antibacterial effect of $3.8 \% \mathrm{Ag}(\mathrm{NH} 3) 2 \mathrm{~F}$ against a $\mathrm{E}$ faecalis biofilm model concluded that $\mathrm{Ag}(\mathrm{NH} 3) 2 \mathrm{~F}$ has potential for use as an antimicrobial root canal irrigant or interappointment medicament to reduce bacterial loads.[37] E faecalis was completely killed by $\mathrm{Ag}(\mathrm{NH} 3$ ) $2 \mathrm{~F}$ after exposure to these agents for $60 \mathrm{~min}$. The silver deposits were found to occlude tubular orifices after removal of the smear layer.

\section{HEBP}

HEBP (1-hydroxyethylidene- 1, 1-bisphosphonate), also known as etidronic acid or etidronate, has been proposed as a potential alternative to EDTA or citric acid because this agent shows no short-term reactivity with $\mathrm{NaOCl}$.[38] HEBP is nontoxic and has been systematically applied to treat bone diseases. [39] The demineralization kinetics promoted by both $9 \%$ HEBP and 18\% HEBP were significantly slower than those of $17 \%$ EDTA.[40] De-Deus et al. reported that the soft chelating irrigation protocol $(18 \%$ HEBP) optimized the bonding quality (3.1-6.1 MPa) of Resilon/ Epiphany®.[41]

\section{Photon-Activated Disinfection}

PDT is based on the concept that nontoxic photosensitizers can be preferentially localized in certain tissues and subsequently activated by light of the appropriate wavelength to generate singlet oxygen and free radicals that are cytotoxic to cells of the target tissue[42].

Methylene blue (MB) is a well-established photosensitizer that has been used in PDT for targeting various gram-positive and gramnegative oral bacteria and was previously used to study the effect of PDT on endodontic disinfection [43-45]. Several studies have shown incomplete destruction of oral biofilms using MB-mediated PDT due to reduced penetration of the photosensitizer [46- 
48]. Soukos et al. used the combined effect of $\mathrm{MB}$ and red light $(665 \mathrm{~nm})$ exhibited up to $97 \%$ reduction of bacterial viability [44].

\section{Herbal Irrigants}

\section{Turmeric(Curcuma Longa)}

Curcumin is a hydrophobic polyphenolic compound that is derived from rhizome of the herb (Curcuma longa) which possesses a wide range of biological applications. It is an yellow bioactive pigment, one of the major constituent of turmeric which has a wide spectrum of biological actions such as anti-inflammatory, antioxidant, antifungal and antibacterial activities.[49]Circumin was incorporation into polymeric fibers which was then tested for its antimicrobial properties and its potential uses in the root canal disinfection. As it is effective an alternative to TAP in controlling the infection, also curcumin requires a minimal concentration of $2.5 \mathrm{mg} / \mathrm{ml}$.Components of the turmeric which are named as curcuminoids ( curcumin or diferuloyl methane, demethoxy curcumin and bisdemethoxycircumin ) as they are polyphenols with a strong antioxidant property .[50][75][76] Recently it had been reported in a study that curcumin in aqueous preparations exhibited a phototoxic effect against gram positive and gram negative bacteria [77]

\section{Liquorice}

Liquorice is an extract from the Glycyrrhiza glabra plant which contains glycyrrhizic acid. Liquorice extract showed the largest zone of inhibition $(3.97 \pm 0.24)$ when compared to mixture of liquorice and calcium hydroxide and $\mathrm{CaOH}$ alone in a study by satti et al[51]. Similarly, Chittrarasu et al[52]. determined that liquorice extract has higher activity than calcium hydroxide against enterococci and better activity on biofilms. The antimicrobial effect of liquorice extract against E. faecalis may be related to the glycyrrhizin[53]

\section{Propolis}

Propolis is a natural product that has gained increased interest due to its antimicrobial activity against a wide range of pathogenic microorganisms. [54] It is composed of resin and balsams (50$60 \%$ ), pollen $(5-10 \%)$, and other constituents like amino acids, minerals, vitamins $\mathrm{A}$ and $\mathrm{B}$ complex, and highly active biochemical substance known as bioflavonoids (vitamin P), phenols, and aromatic compounds. [55] Three studies assessed propolis extracts in different concentrations and solvents $4 \%$ in dimethylsiloxane, $25 \%$ aqueous extract of propolis, and $11 \%$ ethanolic extract of propolis) and $0.9 \%$ saline solution.[56-58] In all of these studies, propolis showed an antimicrobial effect but that was only comparable to that of calcium hydroxide and saline[59].

\section{Triphala}

Triphala is an Indian ayurvedic herbal formulation consisting of dried and powdered fruits of 3 medicinal plants (Terminaliabellerica, Terminaliachebula, Emblicaofficinalis). It has a potential of antibacterial activity and anti-inflammatory activity. he major ingredients of T. bellerica are ellagic and gallic-acid; E. officinalis has several gallic acid derivatives including epigallocatechin gallate and in T. chebulagallic acid is the major ingredient. The presence of these active ingredients of phenolic nature may be responsible to scavenge the free radicals generated by the bacteria. $[60,61]$ Triphala and GTPs are very good chelating agents [62,63] and Triphala, in particular, contains fruits that are rich in citric acid that may aid in removal of the smear layer.

\section{Morinda Citrifolia}

Morinda citrifolia (MCJ) has a broad range of therapeutic effects, including antibacterial, antiviral, antifungal, antitumor, anthelmintic, analgesic, hypotensive, anti inflammatory, and immuneenhancing effects [110-113].MCJ contains the antibacterial compounds L-asperuloside and alizarin[64,65]. Murray et al. proved that, as an intracanal irrigant to remove the smear layer, the efficacy of $6 \% \mathrm{MJC}$ was similar to that of $6 \% \mathrm{NaOCl}$ in conjunction with EDTA [66]. The use of MCJ as an irrigant might be advantageous because it is a biocompatible antioxidant and not likely to cause severe injuries to patients as might occur through $\mathrm{NaOCl}$ accidents. [67]

\section{Aloe Barbadensis(Av)}

Aloe vera consists of the chemical constituent anthraquinones which is responsible for its antibacterial, antiviral and analgesic effects. [68] The reason for its significant increase in microbial load thereby showing reduced efficacy against both E. faecalis and C.albicans is that though AV possess antibacterial effect, the concentration of substances are affected by growth, harvesting, and processing of the aloe leaves therefore it does not have sufficient efficacy due to its dissolution nature. It loses its antibacterial property once it is exposed to the environment. [69]

\section{Azadirachta Indica(Neem)}

Interest on neem is based on its properties like antibacterial, antifungal, antiviral, antioxidant, anti inflammatory, antipyretic and analgesic effects.[68-70] The extracts has undergone extensive pharmacological screening and found to have several pharmacological activities due to the presence of several active constituents like nimbidin, nimbin, nimbolide, gedunin, azadirachtin, mahmoodin, margolone and cyclic trisulphide responsible for its antibacterial action. [70] Its anti-adherence activity by altering bacterial adhesion and the ability of organism to colonize has resulted in AI having the maximum reduction in adherence of $\mathrm{E}$. faecalis to dentin.[71] Use of AI as an endodontic irrigant might be advantageous because it is a biocompatible antioxidant and thus not likely to cause the severe injuries to patients that might occur via $\mathrm{NaOCl}$ accidents. In a study by jaju et al, $0.033 \% \mathrm{AI}$ was highly efficient to $5.25 \% \mathrm{NaOCl}$ in reducing both E. faecalis and C.albicans within the root canals when compared with other extracts. Bitter taste associated with this plant can be altered by different formulations due to addition of sweeteners and flavors to increase the patient's compliance and acceptability. [72] In recent study it has been proven that the neem extract has moderate activity against E.Faecalis , the antimicrobial activity of neem extracts were similar to that of the $17 \%$ of EDTA against E.Faecalis [73]

\section{Green Tea Polyphenols (GTP)}

GTP are derived from fresh leaves of tea (Camellia sinensis), an important component of traditional Japanese and Chinese cultures. They have shown significant antibacterial activity in E. faecalis biofilms grown on dental culture, killing E. faecalis com- 
pletely within $6 \min [65-74]$.

\section{Myristica Frangrans(Mf)}

M. fragrans (both nutmeg and mace) is known to exhibit strong antimicrobial activity against animal and plant pathogens. The constituent responsible for MF for its antibacterial activity is myristic acid.[49]

\section{Terminalia Chebula(Tc)}

Its paste with water is found to be anti-inflammatory, analgesic and having healing capacity for wounds. Its powder is a good astringent dentifrice in loose gums, bleeding and ulceration in gums. The chief constituent; tannin is responsible for the antibacterial action of TC.[73-75]

Our institution is passionate about high quality evidence based research and has excelled in various fields [11][50][76-85]

\section{Antibiotic Intracanal Medicaments}

\section{Septomixine Forte}

Septomixine Forte paste contains dexamethasone, halethazole tartrate, neomycin sulfate, polymyxin B sulfate, and tyrothricin. Septomixine Forte paste, however, is no longer recommended because the antibiotics (neomycin and polymyxin B sulfate) are unsuitable for use against endodontic bacteria due to their inappropriate spectra of activity.[86]

\section{MTAD}

Bio Pure MTAD (Dentsply, Tulsa, OK) is a mixture of a tetracycline isomer, an acetic acid, and Tween 80 detergent (MTAD) was designed to be used as a final root canal rinse before obturation. [87]

Tetracycline has many unique properties of low $\mathrm{pH}$ and thus can act as a calcium chelator and cause enamel and root surface demineralization. [88] MTAD mixture is effective against E. faecalis, and it is also less cytotoxic than a range of endodontic medicaments, including eugenol, hydrogen peroxide $(3 \%)$, EDTA, and calcium hydroxide paste $[65,89,90]$. Ruff et al. showed that $6 \%$ $\mathrm{NaOCl}$ and $2 \%$ chlorohexidine were equally effective and statistically significantly superior to BioPure MTAD and 17\% EDTA in antifungal activity [91][51]. Clegg et al. questioned the ability of MTAD to remove or disrupt bacterial biofilms in root canals [89-92].

\section{Tetraclean}

Tetraclean (OgnaLaboratoriFarmaceutici, Muggiò (Mi), Italy), like MTAD, is a mixture of an antibiotic, an acid, and a detergent. However, the concentration of the antibiotic, doxycycline $(50 \mathrm{mg} / \mathrm{mL}$ ), and the type of detergent (polypropylene glycol) differ from those of MTAD[93]

Giardino et al. compared the surface tension of 17\% EDTA, Cetrexidin, Smear Clear, 5.25\% NaOCl, MTAD and Tetraclean[93]. The $\mathrm{NaOCl}$ and EDTA had the highest surface tension, whereas Cetrexedin and Tetraclean had the lowest values[50].Only the
$\mathrm{NaOCl}$ could disaggregate and remove the biofilm at every time interval tested although treatment with Tetraclean caused a high degree of biofilm disaggregation at each time interval when compared with MTAD[94].

\section{Triple Antibiotic Paste}

Combination of antibiotics are required for the reduction of likelihood of the development of resistant bacterial strains like a combination of Metronidazole, Ciprofloxacin and Minocycline[95]. The use of TAP contains metronidazole of $500 \mathrm{mg}$, ciprofloxacin of $200 \mathrm{mg}$ and minocycline of $100 \mathrm{mg}$ in the ratio of 1:1:1 as recommended by Hoshino et al.[96]. TAP is radiolucent[96], propylene glycol as a vehicle of TAP may be difficult to remove from the dentin surface, an additional appointment is required to remove TAP and re-opening the tooth to remove TAP introduces a risk of recontamination. Antibiotic containing scaffolds can solve the problems.

Bottino MC et al.[97] have suggested that the polymer-based antibiotic-containing electrospun scaffolds may act as a biologically safe antimicrobial drug delivery system for regenerative endodontics. This can improve drug delivery due to high surface area fibers arranged in an interconnecting structure that allows controlled drug release[98]

\section{Conclusion}

During instrumentation canals should be irrigated using copious amounts of irrigants. The use of antibiotics containing dental agents should be carefully justified, in order to avoid bacterial resistance. Future studies of irrigants should focus on the production of a single solution that is biocompatible, has tissue-solubilizing properties, removes the smear layer, and has antibacterial effects.

\section{References}

[1]. Murray PE, Farber RM, Namerow KN, Kuttler S, Garcia-Godoy F. Evaluation of Morinda citrifolia as an endodontic irrigant. J Endod. 2008 Jan;34(1):66-70. Pubmed PMID: 18155496.

[2]. Mohammadi Z. An update on the antibiotic-based root canal irrigation solutions. Iran Endod J. 2008 Spring:3(2):1-7. Pubmed PMID: 24171012.

[3]. KAKEHASHI S, STANLEY HR, FITZGERALD RJ. THE EFFECTS OF SURGICAL EXPOSURES OF DENTAL PULPS IN GERM-FREE AND CONVENTIONAL LABORATORY RATS. Oral Surg Oral Med Oral Pathol. 1965 Sep;20:340-9. Pubmed PMID: 14342926.

[4]. El Karim I, Kennedy J, Hussey D. The antimicrobial effects of root canal irrigation and medication. Oral Surg Oral Med Oral Pathol Oral Radiol Endod. 2007 Apr;103(4):560-9. Pubmed PMID: 17223590.

[5]. Lin LM, Skribner JE, Gaengler P. Factors associated with endodontic treatment failures. J Endod. 1992 Dec;18(12):625-7. Pubmed PMID: 1298804

[6]. Molander A, Reit C, Dahlén G, Kvist T. Microbiological status of root-filled teeth with apical periodontitis. Int Endod J. 1998 Jan;31(1):1-7. Pubmed PMID: 9823122.

[7]. Govindaraju L, Gurunathan D. Effectiveness of Chewable Tooth Brush in Children-A Prospective Clinical Study. J Clin Diagn Res. 2017 Mar;11(3):ZC31-ZC34. Pubmed PMID: 28511505.

[8]. Christabel A, Anantanarayanan P, Subash P, Soh CL, Ramanathan M, Muthusekhar MR, et al. Comparison of pterygomaxillary dysjunction with tuberosity separation in isolated Le Fort I osteotomies: a prospective, multi-centre, triple-blind, randomized controlled trial. Int J Oral Maxillofac Surg. 2016 Feb;45(2):180-5. Pubmed PMID: 26338075.

[9]. Soh CL, Narayanan V. Quality of life assessment in patients with dentofacial deformity undergoing orthognathic surgery--a systematic review. Int J Oral Maxillofac Surg. 2013 Aug;42(8):974-80. Pubmed PMID: 23702370.

[10]. Mehta M, Deeksha, Tewari D, Gupta G, Awasthi R, Singh H, et al. Oligo- 
nucleotide therapy: An emerging focus area for drug delivery in chronic inflammatory respiratory diseases. Chem Biol Interact. 2019 Aug 1;308:206215. Pubmed PMID: 31136735.

[11]. Ezhilarasan D, Apoorva VS, Ashok Vardhan N. Syzygium cumini extract induced reactive oxygen species-mediated apoptosis in human oral squamous carcinoma cells. J Oral Pathol Med. 2019 Feb;48(2):115-121. Pubmed PMID: 30451321.

[12]. Campeau PM, Kasperaviciute D, Lu JT, Burrage LC, Kim C, Hori M, et al. The genetic basis of DOORS syndrome: an exome-sequencing study. Lancet Neurol. 2014 Jan;13(1):44-58. Pubmed PMID: 24291220

[13]. Kumar S, Sneha S. Knowledge and awareness regarding antibiotic prophylaxis for infective endocarditis among undergraduate dental students. Asian Journal of Pharmaceutical and Clinical Research. 2016;154.

[14]. Christabel SL, Gurunathan D. Prevalence of type of frenal attachment and morphology of frenum in children, Chennai, Tamil Nadu. World J Dent. 2015 Oct;6(4):203-7.

[15]. Kumar S, Rahman RE. Knowledge, awareness, and practices regarding biomedical waste management among undergraduate dental students. Asian Journal of Pharmaceutical and Clinical Research. 2017;10(8):341.

[16]. Sridharan G, Ramani P, Patankar S. Serum metabolomics in oral leukoplakia and oral squamous cell carcinoma. J Cancer Res Ther. 2017 JulSep;13(3):556-561. Pubmed PMID: 28862226.

[17]. Ramesh A, Varghese SS, Doraiswamy JN, Malaiappan S. Herbs as an antioxidant arsenal for periodontal diseases. J Intercult Ethnopharmacol. 2016 Jan 27;5(1):92-6. Pubmed PMID: 27069730.

[18]. Thamaraiselvan M, Elavarasu S, Thangakumaran S, Gadagi JS, Arthie T. Comparative clinical evaluation of coronally advanced flap with or without platelet rich fibrin membrane in the treatment of isolated gingival recession. J Indian Soc Periodontol. 2015 Jan-Feb;19(1):66-71. Pubmed PMID: 25810596

[19]. Thangaraj SV, Shyamsundar V, Krishnamurthy A, Ramani P, Ganesan K, Muthuswami M, et al. Molecular Portrait of Oral Tongue Squamous Cell Carcinoma Shown by Integrative Meta-Analysis of Expression Profiles with Validations. PLoS One. 2016 Jun 9;11(6):e0156582. Pubmed PMID: 27280700.

[20]. Ponnulakshmi R, Shyamaladevi B, Vijayalakshmi P, Selvaraj J. In silico and in vivo analysis to identify the antidiabetic activity of beta sitosterol in adipose tissue of high fat diet and sucrose induced type- 2 diabetic experimental rats. Toxicol Mech Methods. 2019 May;29(4):276-290. Pubmed PMID: 30461321

[21]. Ramakrishnan M, Bhurki M. Fluoride, Fluoridated Toothpaste Efficacy And Its Safety In Children-Review. International Journal of Pharmaceutical Research. 2018 Oct 1;10(04):109-14.

[22]. Zehnder M. Root canal irrigants. J Endod. 2006 May;32(5):389-98. Pubmed PMID: 16631834.

[23]. Haapasalo M, Shen Y, Qian W, Gao Y. Irrigation in endodontics. Dent Clin North Am. 2010 Apr;54(2):291-312. Pubmed PMID: 20433979.

[24]. Ma J, Wang Z, Shen Y, Haapasalo M. A new noninvasive model to study the effectiveness of dentin disinfection by using confocal laser scanning microscopy. J Endod. 2011 Oct;37(10):1380-5. Pubmed PMID: 21924186.

[25]. McDonnell G, Russell AD. Antiseptics and disinfectants: activity, action, and resistance. Clin Microbiol Rev. 1999 Jan;12(1):147-79. Erratum in: Clin Microbiol Rev 2001 Jan;14(1):227. Pubmed PMID: 9880479.

[26]. Zambon JJ, Reynolds HS, Dunford RG, Bonta CY. Effect of a triclosan/ copolymer/fluoride dentifrice on the oral microflora. Am J Dent. 1990 Sep;3 Spec No:S27-34. Pubmed PMID: 2083042.

[27]. Watson RR, Preedy VR, editors. Bioactive Food as Dietary Interventions for the Aging Population: Bioactive Foods in Chronic Disease States. Academic Press; 2012 Oct 22

[28]. Selkon JB, Babb JR, Morris R. Evaluation of the antimicrobial activity of a new super-oxidized water, Sterilox, for the disinfection of endoscopes. J Hosp Infect. 1999 Jan;41(1):59-70. Pubmed PMID: 9949966.

[29]. Hata G, Uemura M, Weine FS, Toda T. Removal of smear layer in the root canal using oxidative potential water. J Endod. 1996 Dec;22(12):643-5. Pubmed PMID: 9220747.

[30]. Baumgartner JC, Mader CL. A scanning electron microscopic evaluation of four root canal irrigation regimens. J Endod. 1987 Apr;13(4):147-57. Pubmed PMID: 3106553.

[31]. Broadwater WT, Hoehn RC, King PH. Sensitivity of three selected bacterial species to ozone. Appl Microbiol. 1973 Sep;26(3):391-3. Pubmed PMID: 4201643.

[32]. Baysan A, Lynch E. The use of ozone in dentistry and medicine. Prim Dent Care. 2005 Apr;12(2):47-52. Pubmed PMID: 15901432

[33]. Hmud R, Kahler WA, George R, Walsh LJ. Cavitational effects in aqueous endodontic irrigants generated by near-infrared lasers. J Endod. 2010 Feb;36(2):275-8. Pubmed PMID: 20113789.
[34]. Hems RS, Gulabivala K, Ng YL, Ready D, Spratt DA. An in vitro evaluation of the ability of ozone to kill a strain of Enterococcus faecalis. Int Endod J. 2005 Jan;38(1):22-9. Pubmed PMID: 15606819.

[35]. Ibrahim NZ. Antimicrobial Evaluation of Sodium Hypochlorite and Ozonated Water on E. Faecalis Biofilm. JabatanPemeliharaan Gigi, FakultiPergigian, Universiti Malaya.2007.

[36]. Eto JN, Niu W, Takeda FH, Kimura Y, Matsumoto K. Morphological and atomic analytical changes of root canal wall dentin after treatment with thirty-eight percent $\mathrm{Ag}(\mathrm{NH} 3) 2 \mathrm{~F}$ solution and $\mathrm{CO} 2$ laser. J Clin Laser Med Surg. 1999 Feb;17(1):19-24. Pubmed PMID: 10204444.

[37]. Hiraishi N, Yiu CK, King NM, Tagami J, Tay FR. Antimicrobial efficacy of $3.8 \%$ silver diamine fluoride and its effect on root dentin. J Endod. 2010 Jun;36(6):1026-9. Pubmed PMID: 20478459.

[38]. Zehnder M, Schmidlin P, Sener B, Waltimo T. Chelation in root canal therapy reconsidered. J Endod. 2005 Nov;31(11):817-20. Pubmed PMID: 16249726.

[39]. Russell RG, Rogers MJ. Bisphosphonates: from the laboratory to the clinic and back again. Bone. 1999 Jul;25(1):97-106. Pubmed PMID: 10423031.

[40]. Matthews IL, Reynolds II, Robertson WG, Simkiss K. Biological Mineralization and Demineralization: Report of the Dahlem Workshop on Biological Mineralization and Demineralization Berlin 1981, October 18-23. Springer Science \& Business Media; 2012 Dec 6.

[41]. De-Deus G, Namen F, Galan J Jr, Zehnder M. Soft chelating irrigation protocol optimizes bonding quality of Resilon/Epiphany root fillings. J Endod. 2008 Jun;34(6):703-5. Pubmed PMID: 18498893.

[42]. Dougherty TJ, Gomer CJ, Henderson BW, Jori G, Kessel D, Korbelik M, et al. Photodynamic therapy. JNCI: Journal of the national cancer institute. 1998 Jun 17;90(12):889-905.

[43]. Harris F, Chatfield LK, Phoenix DA. Phenothiazinium based photosensitisers--photodynamic agents with a multiplicity of cellular targets and clinical applications. Curr Drug Targets. 2005 Aug;6(5):615-27. Pubmed PMID: 16026282.

[44]. Soukos NS, Chen PS, Morris JT, Ruggiero K, Abernethy AD, Som S, et al. Photodynamic therapy for endodontic disinfection. J Endod. 2006 Oct;32(10):979-84. Pubmed PMID: 16982278

[45]. George S, Kishen A. Advanced noninvasive light-activated disinfection: assessment of cytotoxicity on fibroblast versus antimicrobial activity against Enterococcus faecalis. J Endod. 2007 May;33(5):599-602. Pubmed PMID: 17437881.

[46]. Soukos NS, Socransky SS, Mulholland SE, Lee S, Doukas AG. Photomechanical drug delivery into bacterial biofilms. Pharm Res. 2000 Apr;17(4):405-9. Pubmed PMID: 10870983.

[47]. Ogura M, Abernethy AD, Blissett RD, Ruggiero K, Som S, Goodson JM, et al. Photomechanical wave-assisted molecular delivery in oral biofilms. World Journal of Microbiology and Biotechnology. 2007 Nov;23(11):1637-46

[48]. Müller P, Guggenheim B, Schmidlin PR. Efficacy of gasiform ozone and photodynamic therapy on a multispecies oral biofilm in vitro. Eur J Oral Sci. 2007 Feb;115(1):77-80. Pubmed PMID: 17305720.

[49]. Nada GA, Talet Y, Nayyarjehan M, Samia A. Studies of the antibacterial effect of different fraction of Curcuma longa against urinary tract infections Isolation. Pakistan Journal of Biological Sciences. 2004;7(12):2055-60.

[50]. Neelakantan P, Subbarao C, Sharma S, Subbarao CV, Garcia-Godoy F, Gutmann JL. Effectiveness of curcumin against Enterococcus faecalis biofilm. Acta Odontol Scand. 2013 Nov;71(6):1453-7. Pubmed PMID: 23394209.

[51]. Satti P, Kakarla P, Jogendra Avula SS, Muppa R, Kiran Rompicharla SV, Biswas S. Indigenous irrigants as potent antimicrobials in endodontic treatment: An in vitro study. J Indian Soc Pedod Prev Dent. 2019 JulSep;37(3):275-281. Pubmed PMID: 31584028.

[52]. Chittrarasu M, Sathyanarayana SS, Ahamed S, Aberna A, Bhavani S, Rajaraman G. Antimicrobial efficacy of liquorice against Enterococcus faecalis biofilms in various concentrations at time-dependent variables: $\mathrm{An}$ in vitro study. J Conserv Dent. 2019 Jan-Feb;22(1):7-11. Pubmed PMID 30820075.

[53]. Jain P, Sontakke P, Walia S, Yadav P, Biswas G, Kaur D. Assessment of the efficacy of licorice versus $0.2 \%$ chlorhexidine oral rinse on plaque-induced gingivitis: A randomized clinical trial. Indian Journal of Oral Health and Research. 2017 Jan 1;3(1):15.

[54]. Santos FA, Bastos EM, Maia AB, Uzeda M, Carvalho MA, Farias LM, et al. Brazilian propolis: physicochemical properties, plant origin and antibacterial activity on periodontopathogens. Phytother Res. 2003 Mar; 17(3):285-9. Pubmed PMID: 12672164.

[55]. Rathod S, Brahmankar R, Kolte A. Propolis-A natural remedy. Indian J Dent Res Rev. 2012;50:99-103.

[56]. Jolly M, Singh N, Rathore M, Tandon S, Banerjee M. Propolis and commonly used intracanal irrigants: comparative evaluation of antimicrobial potential. J Clin Pediatr Dent. 2013 Spring;37(3):243-9. Pubmed PMID: 
23855167

[57]. Verma MK, Pandey RK, Khanna R, Agarwal J. The antimicrobial effectiveness of $25 \%$ propolis extract in root canal irrigation of primary teeth. J Indian Soc Pedod Prev Dent. 2014 Apr-Jun;32(2):120-4. Pubmed PMID: 24739910.

[58]. Divya S, Sujatha S. Evaluation of Antimicrobial effect of Triphala versus conventional root canal irrigants in primary teeth-An In vivo study. Research Journal of Pharmacy and Technology. 2019 Feb 1;12(2):655-9.

[59]. Agnihotri A, Arora R, Sharma U, Sood P. Herbal irrigants in primary teeth: A step toward green dentistry based on the wisdom of past. Journal of Indian Association of Public Health Dentistry. 2020 Oct 1;18(4):279.

[60]. Sabu MC, Kuttan R. Anti-diabetic activity of medicinal plants and its relationship with their antioxidant property. J Ethnopharmacol. 2002 Jul;81(2):155-60. Pubmed PMID: 12065146.

[61]. Garg P, Tyagi SP, Sinha DJ, Singh UP, Malik V, Maccune ER. Comparison of antimicrobial efficacy of propolis, Morinda citrifolia, Azadirachta indica, triphala, green tea polyphenols and 5.25\% sodium hypochlorite against Enterococcus fecalis biofilm. Saudi Endod J. 2014 Aug;4(3):122-7.

[62]. Jagetia GC, Malagi KJ, Baliga MS, Venkatesh P, Veruva RR. Triphala, an ayurvedic rasayana drug, protects mice against radiation-induced lethality by free-radical scavenging. J Altern Complement Med. 2004 Dec;10(6):971-8. Pubmed PMID: 15673991

[63]. Zhao CN, Tang GY, Cao SY, Xu XY, Gan RY, Liu Q, et al. Phenolic Profiles and Antioxidant Activities of 30 Tea Infusions from Green, Black, Oolong, White, Yellow and Dark Teas. Antioxidants (Basel). 2019 Jul 10;8(7):215. Pubmed PMID: 31295859

[64]. Nudera WJ, Fayad MI, Johnson BR, Zhu M, Wenckus CS, Begole EA, et al. Antimicrobial effect of triclosan and triclosan with Gantrez on five common endodontic pathogens. J Endod. 2007 Oct;33(10):1239-42. Pubmed PMID: 17889698.

[65]. Prabhakar J, Senthilkumar M, Priya MS, Mahalakshmi K, Sehgal PK, Sukumaran VG. Evaluation of antimicrobial efficacy of herbal alternatives (Triphala and green tea polyphenols), MTAD, and 5\% sodium hypochlorite against Enterococcus faecalis biofilm formed on tooth substrate: an in vitro study. J Endod. 2010 Jan;36(1):83-6. Pubmed PMID: 20003940

[66]. Wang MY, West BJ, Jensen CJ, Nowicki D, Su C, Palu AK, et al. Morinda citrifolia (Noni): a literature review and recent advances in Noni research. Acta Pharmacol Sin. 2002 Dec;23(12):1127-41. Pubmed PMID: 12466051.

[67]. Gu LS, Kim JR, Ling J, Choi KK, Pashley DH, Tay FR. Review of contemporary irrigant agitation techniques and devices. J Endod. 2009 Jun;35(6):791804. Pubmed PMID: 19482174.

[68]. Biswas K, Chattopadhyay I, Banerjee RK, Bandyopadhyay U. Biological activities and medicinal properties of neem (Azadirachta indica). Current science. 2002 Jun 10:1336-45.

[69]. Ramachandra CT, Rao PS. Processing of Aloe vera leaf gel: a review. American Journal of Agricultural and Biological Sciences. 2008;3(2):502-10

[70]. Balasenthil S, Arivazhagan S, Ramachandran CR, Ramachandran V, Nagini S. Chemopreventive potential of neem (Azadirachta indica) on 7,12-dimethylbenz[a]anthracene (DMBA) induced hamster buccal pouch carcinogenesis. J Ethnopharmacol. 1999 Nov 1;67(2):189-95. Pubmed PMID: 10619383.

[71]. Polaquini SR, Svidzinski TI, Kemmelmeier C, Gasparetto A. Effect of aqueous extract from Neem (Azadirachta indica A. Juss) on hydrophobicity, biofilm formation and adhesion in composite resin by Candida albicans. Arch Oral Biol. 2006 Jun;51(6):482-90. Pubmed PMID: 16412377.

[72]. Vinothkumar TS, Rubin MI, Balaji L, Kandaswamy D. In vitro evaluation of five different herbal extracts as an antimicrobial endodontic irrigant using real time quantitative polymerase chain reaction. J Conserv Dent. 2013 Mar;16(2):167-70. Pubmed PMID: 23716972.

[73]. Siddique R, Nivedhitha MS, Jacob B. Quantitative analysis for detection of toxic elements in various irrigants, their combination (precipitate), and para-chloroaniline: An inductively coupled plasma mass spectrometry study. J Conserv Dent. 2019 Jul-Aug;22(4):344-350. Pubmed PMID: 31802817.

[74]. Hamilton-Miller JMT. Anti-cariogenic properties of tea (Camellia sinensis). J Med Microbiol. 2001 Apr;50(4):299-302. Pubmed PMID: 11289514

[75]. Alemdar S, Agaoglu S. Investigation of in vitro antimicrobial activity of aloe vera juice. Journal of animal and veterinary advances. 2009;8(1):99-102

[76]. Vijayashree Priyadharsini J. In silico validation of the non-antibiotic drugs acetaminophen and ibuprofen as antibacterial agents against red complex pathogens. J Periodontol. 2019 Dec;90(12):1441-1448. Pubmed PMID: 31257588

[77]. J PC, Marimuthu T, C K, Devadoss P, Kumar SM. Prevalence and measurement of anterior loop of the mandibular canal using CBCT: A cross sectional study. Clin Implant Dent Relat Res. 2018 Aug;20(4):531-534. Pubmed PMID: 29624863.
[78]. Ramesh A, Varghese S, Jayakumar ND, Malaiappan S. Comparative estimation of sulfiredoxin levels between chronic periodontitis and healthy patients A case-control study. J Periodontol. 2018 Oct;89(10):1241-1248. Pubmed PMID: 30044495.

[79]. Ramadurai N, Gurunathan D, Samuel AV, Subramanian E, Rodrigues SJL. Effectiveness of 2\% Articaine as an anesthetic agent in children: randomized controlled trial. Clin Oral Investig. 2019 Sep;23(9):3543-3550. Pubmed PMID: 30552590

[80]. Sridharan G, Ramani P, Patankar S, Vijayaraghavan R. Evaluation of salivary metabolomics in oral leukoplakia and oral squamous cell carcinoma. J Oral Pathol Med. 2019 Apr:48(4):299-306. Pubmed PMID: 30714209.

[81]. Mathew MG, Samuel SR, Soni AJ, Roopa KB. Evaluation of adhesion of Streptococcus mutans, plaque accumulation on zirconia and stainless steel crowns, and surrounding gingival inflammation in primary molars: randomized controlled trial. Clin Oral Investig. 2020 Sep;24(9):3275-3280. Pubmed PMID: 31955271.

[82]. Samuel SR. Can 5-year-olds sensibly self-report the impact of developmental enamel defects on their quality of life? Int J Paediatr Dent. 2021 Mar;31(2):285-286. Pubmed PMID: 32416620.

[83]. R H, Ramani P, Ramanathan A, R JM, S G, Ramasubramanian A, et al. CYP2 C9 polymorphism among patients with oral squamous cell carcinoma and its role in altering the metabolism of benzo[a]pyrene. Oral Surg Oral Med Oral Pathol Oral Radiol. 2020 Sep;130(3):306-312. Pubmed PMID: 32773350 .

[84]. Chandrasekar R, Chandrasekhar S, Sundari KKS, Ravi P. Development and validation of a formula for objective assessment of cervical vertebral bone age. Prog Orthod. 2020 Oct 12;21(1):38. Pubmed PMID: 33043408.

[85]. Vijayashree Priyadharsini J, Smiline Girija AS, Paramasivam A. In silico analysis of virulence genes in an emerging dental pathogen A. baumannii and related species. Arch Oral Biol. 2018 Oct;94:93-98. Pubmed PMID: 30015217.

[86]. Athanassiadis B, Abbott PV, Walsh LJ. The use of calcium hydroxide, antibiotics and biocides as antimicrobial medicaments in endodontics. Aust Dent J. 2007 Mar;52(1 Suppl):S64-82. Pubmed PMID: 17546863.

[87]. Torabinejad M, Khademi AA, Babagoli J, Cho Y, Johnson WB, Bozhilov $\mathrm{K}$, et al. A new solution for the removal of the smear layer. J Endod. 2003 Mar:29(3):170-5. Pubmed PMID: 12669874

[88]. Bjorvatn K, Skaug N, Selvig KA. Tetracycline-impregnated enamel and dentin: duration of antimicrobial capacity. Scand J Dent Res. 1985 Jun;93(3):192-7. Pubmed PMID: 3860902.

[89]. Zhang W, Torabinejad M, Li Y. Evaluation of cytotoxicity of MTAD using the MTT-tetrazolium method. J Endod. 2003 Oct;29(10):654-7. Pubmed PMID: 14606789

[90]. Torabinejad M, Shabahang S, Aprecio RM, Kettering JD. The antimicrobial effect of MTAD: an in vitro investigation. J Endod. 2003 Jun;29(6):400-3. Pubmed PMID: 12814224.

[91]. Ruff ML, McClanahan SB, Babel BS. In vitro antifungal efficacy of four irrigants as a final rinse. J Endod. 2006 Apr;32(4):331-3. Pubmed PMID: 16554205.

[92]. Clegg MS, Vertucci FJ, Walker C, Belanger M, Britto LR. The effect of exposure to irrigant solutions on apical dentin biofilms in vitro. J Endod. 2006 May;32(5):434-7. Pubmed PMID: 16631843.

[93]. Giardino L, Ambu E, Becce C, Rimondini L, Morra M. Surface tension comparison of four common root canal irrigants and two new irrigants containing antibiotic. J Endod. 2006 Nov;32(11):1091-3. Pubmed PMID: 17055914 .

[94]. Giardino L, Ambu E, Savoldi E, Rimondini R, Cassanelli C, Debbia EA. Comparative evaluation of antimicrobial efficacy of sodium hypochlorite, MTAD, and Tetraclean against Enterococcus faecalis biofilm. J Endod. 2007 Jul;33(7):852-5. Pubmed PMID: 17804328.

[95]. Somasundaram S, Subramanyam D. Evaluation of stability and antibacterial activity of various concentrations of triple antibiotic paste against Enterococcus faecalis: An in vitro study. World J Dent. 2017;8:403-406.

[96]. Hoshino E, Kurihara-Ando N, Sato I, Uematsu H, Sato M, Kota K, et al. Invitro antibacterial susceptibility of bacteria taken from infected root dentine to a mixture of ciprofloxacin, metronidazole and minocycline. Int Endod J. 1996 Mar;29(2):125-30. Pubmed PMID: 9206436.

[97]. Thakur RA, Florek CA, Kohn J, Michniak BB. Electrospun nanofibrous polymeric scaffold with targeted drug release profiles for potential application as wound dressing. Int J Pharm. 2008 Nov 19;364(1):87-93. Pubmed PMID: 18771719

[98]. Cui W, Zhou Y, Chang J. Electrospun nanofibrous materials for tissue engineering and drug delivery. Sci Technol Adv Mater. 2010 Mar 18;11(1):014108. Pubmed PMID: 27877323. 